\title{
研究
}

\section{アミノ配糖体系抗生物質による内耳障害様式 に関する実験的研究}

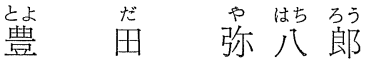

緒 言

1946年, Brown and Hinshaw ${ }^{3)}$ がストレプトマイシンによる.物覚障害につ いて報告して以来, 臨床的にストレプトマイシン, カナマイシンなどのアミノ配糖体系抗生物質が その副作用として，時に重篤な聴平衡覚障害を来すととが明らかにされてきた。 その後，てれらの

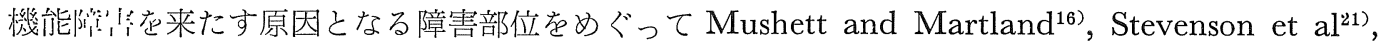
Rüedi et $\mathrm{al}^{18)}$, Floberg et $\mathrm{al}^{8)}$ らの報告が見られ，第八神経領域の種々の部位べし夜 変化が報告されているが，1951年，Berg ${ }^{2)}$ がストレプトマイシンの侵襲の第一義的な部位が，内耳 末梢受容器の感覚細胞であるととを実験的に明らかにして，アミノ配糖体系抗生物質による聴平 衡覚障害の病理はほほ確立した。しかし，その後の多くの臨床的，実験的研究の成果にもかかわら

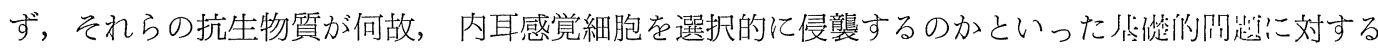
解可は圲作洷るまで成功しているとはいえない。

今回，著者は Engström ${ }^{5)}$ 鈴木 ${ }^{23)}, L^{2}$ Lindemann ${ }^{12)}$ らにより開発されたコルチ器および前庭感覚 器の surface preparation の方法を用いて，ストレプトマイシンおよびカナマイシンによる内耳毛 細胞障害の様式をコルチ器と ㄱ. 物質による毛細胞障害の本質を示唆する結果を得たので報告する。

\section{実験目的および実験方法}

\section{実験目的}

カナマイシン（以下KMと略す）の侵襲部位 は臨床的にも実験的にも前庭系より聴覚系によ り強く偏在しているとと, 逆に硫酸ストレプト マイシン（以下 SMと略す）では前庭系の障害 がより優位であるととは，今日までの多くの研 究の結果認められている事実である。しかし， KMと SMではその化学構造がほんの僅か異っ ているだけにもかかわらず，内耳での侵襲部位
が何故てのように明らかに異るかといった問題 については，今日なお明確な解答は得られてい ない。ての!!いい高としては次の二通りのて とが考えられる。

1) 前庭系と聴覚系でそれぞれの部位の毛細 胞にKMおよび SMに対する細胞レベルでの感 受性の差が存在する。

2) 細胞レベルでの感受性には差がなく，毛

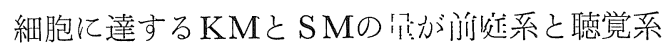

An Experimental Study upon the Mode of Inner Ear Destruction of Guinea Pig by Kanamycin and Streptomycin sulfate

Yahachiro Toyoda

京都府立医科大学耳鼻咽喉科学教室（主任：水越 治教授） 
で異なる。

このいずれが正しい考え方であるかを直接的 な方法で知ることは困難である。しかし，KM および SMを筋肉内あるいは腹腔内に全身的に 投与し血行を介して毛細胞に達せしめると，上 述したように両者で障害部位が異なってくる が，たとえばKMおよび SMを鼓室内に直接注 入して，毛細胞に達する経路を変えて実験した らてれらの障害部位が変化するかどうかなどの 間接的な方法でこれらの抗生物質の内耳障害の 本質を示唆する傍証を得られるかも知れないと 考えた。すなわち，鼓室内に注入した場合に は，KMもSMも㧈そらく主として正円䈍を介 して，一部は卵円空の国门比較的薄い結 合組織の間隙を介して，直接鼓室階外リンパ腔 および前庭階外リンパ腔に侵入し，その後血行 を介さずにコルチ器および前庭器毛細胞に移行 するものと考光られ，全身投与の場合とは明ら かに異った経路で毛細胞はKMや SMにさらさ れると思われる。鼓室内に大量の $\mathrm{KM}, \mathrm{SM}$ 注入すると，全身投与の場合より明らかに高濃 度の $\mathrm{KM}, \mathrm{SM}$ が急速に内耳に浸透し, 毛細胞 は短時間の間に急激な変化を受けるものと考え られ，乙の際，注入後一定時間を経れば，螖牛 内においても，前庭系内においてもほぼ同じ濃 度の大量の $\mathrm{KM} お$ よび $\mathrm{S} M$ ガ侵入しているもの と思われる。乙のような条件下で，なお $\mathrm{KM}$ 注入した場合にはコルチ器毛細胞がより強く障 害され，SMを注入した場合には前庭系毛細胞 がより強く障害されるとすれば，前庭系と聴覚 系でKM，SMに対する毛細胞レベルでの易傷 性の差を認めるこができ，一方，ての方法では KMとSMでそれぞれ特異的な障害部位の差を 形成し得ないとすれば，全身投与されたKM， SMがそれぞれいずれかの部位で聴覚系と前庭 系へふり分けられるために障害部位に特異な差 を生ずるという可能性を認めることができる。 この結果から，とりもなおさず毛細胞がアミノ 配糖体系抗生物質に特異的に障害され易いため に内耳障害を来たすのか，あるいは毛細胞が特
にてれらの抗生物質に弱いのではなく，他の物 質に比して,アミノ配糖体が特に内耳へ移行し 易い（あるいは停滞し易い）ために毛細胞内代 謝が阻害されて内耳障害をひきおてすのかの解 答をも示唆するものと考光られ，毛細胞障害機 構の本質にせまるととができる。

以上の事実を確める目的で今回の実験を企図 した。

\section{実験方法}

i ）実験材材および投与方法

実験には体重200～400 g のプライエル反射正 常成熟赤目モルモットを使用した。投与楽剤は カナマイシン $(\mathrm{KM})$ と硫酸ストレプトマイシ ン（ $\mathrm{SM}$ )の両者である。投与は動物をエーテ ル全身麻酔にて安静にし，耳鏡を通じて動物の 左側鼓膜を明視しつつ注射針にて注意深く $\mathrm{KM}$ か SMを鼓室内に注入した。注入に際し，注入 孔より薬液があふれ出る点を終了点として測定 したところ約 $0.5 \mathrm{ml}$ 注入できた。右耳は対照と した。

薬剤の総投与量は以下の通りである。

$\mathrm{SM}$ と KMの内耳への影響の仕方を比較する ために，まず動物を二群に分け，200 $\mathrm{mg} / \mathrm{ml} の$ 濃度になるように㷛溜水で浴解したKMを投与 した群と，同濃度のSMを投与した群を作って 比較検討した，投与後，右耳は対照として，無 処理にしたのでプライエル反射は残っており， 投与側の聴力の経時的变化は電気生理学的方法 を用いる以外の手段で!彽然できなかったが， 動物はKMを投与した群でも，SMを投与した 群でも，投与後 $3 \sim 4$ 時間で非注入側に向う水 平性自発眼振を示し，投与側への転倒傾向を示

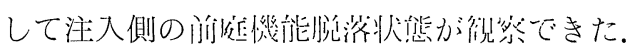
この平衡湢影 1 日で代償されるものである

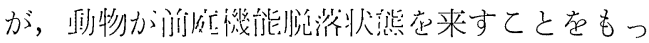
て薬浏の注入が成功したと判定して以下の実験 の材料に供した。投与は 1 回にとどめ, 投与後

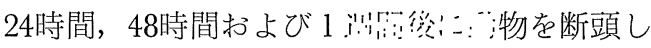
て内耳障害の程度を観察した。投与後三種の経 過時間をおいて観察したのは，投与後の経時的 
変化を観察すると共に, initial lesionが内耳の いずれの部位に現われるかを知るためである.

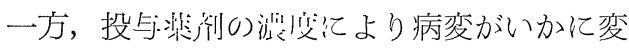
化するかを知る目的で，KM， SMともそれぞ れ $50 \mathrm{mg} / \mathrm{ml}, 100 \mathrm{mg} / \mathrm{ml}, 200 \mathrm{mg} / \mathrm{ml}$ 濃度の 水溶液を作って投与した。乙れらの動物はいず れも 1 遡间後に䉼頭して観察した。

鼓室内注入法は 1 回の投与で確実に内耳病変 を作り得る簡便な方法であるが，一方で非常に 高濃度の薬剂を注入するために，投与薬剤のも

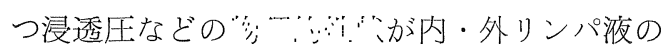
それと著しく異なり，特異的な内耳毒性による 障害とともに，毛細胞膜に物理的障害を来す可 能性があり，したがって常にそのととを念頭に おいた対照を設定する必要がある。そのため に，1群は生理的食塩水を投与して，リンパ液

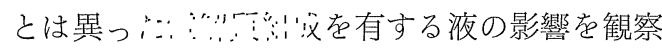

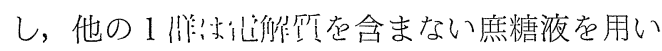

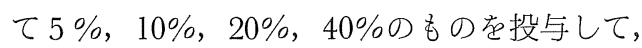

浸透圧の影響を観察した。

\section{ii ) 観察方法}

前項のごとく処置した動物を断頭後, 耳骨胞 を切離し，骨胞を解放して双服实休频微鉝下に 蝸牛・前庭器官の骨壁を解放して膜迷路を露出 した．生存毛細胞のみを撰択的に染色する目的 で, succinic dehydrogenase (SDH) 染色を ほどしした。染色のための反応液は Nachla の 処方に準じ，1 時間反応せしめたのち，10\%中 性フォルマリンに24時間以上冷蔵固定して観察 した.

コルチ器は各回転別に surface preparation をおこない，グリセリンに封入して光”频微銧 下に観察した。前庭器官は球形のう, 卵形のう 平衡斑および水平・前・後三半規管膨大部稜の 感览䊶肔问を細い注射針で注意深く剝離して, コルチ器同様グリセリンに封入して光少䖨微銧 下に観察した。

\section{実 験 結 果}

\section{$\mathrm{KM}$ と SM での障害様式の比較}

KM, SMの各々による毛細胞障害様式の比 較は，それぞれ前項で述べたでとく $200 \mathrm{mg} / \mathrm{ml}$ の濃度を有する水溶液を注入して 1 週間を経過 した内耳を用いて観察，比較検討した。標本と した内耳は 1 耳でとに蝸牛各回転, 卵形球形両 平衡斑および三半規管膨大部棱をすべて観察し て全体の障害様式を比較通覧し考察した。

全体的にみて最も特微的なととは，全身投与 の場合と違って，KMKよる変化と SMKよる 変化とでその障害部位，障害程度ともに有意の 差を示さなかった事実である.

コルチ器における病変をKM, SMの両者に ついて共通の変化として以下に述べる。

コルチ器上方回転では, 内毛細胞 (以下 $\mathrm{IHC}$ と略す) の紃胞休沙失が外毛細胞 (以下 $\mathrm{OHC}$ と略す）の消失に比してょり高度であった。 $\mathrm{OHC}$ は第 I 列（最内列すなわちコルチトンネ ル側の列)，第 II列（中央列）で消失している

が，第而列（最外列すなわち Deiters 細胞側の 列）にはまだ光顕的に健常な細胞を残している 段階で， IHC はすでにすべて消失している像 が認められた。また，毛細胞障害の程度が軽度 で，上方回転 $\mathrm{OHG}$ 亿変化の認められなかっ た内耳でも IHG はすでにかなりの程度に障害

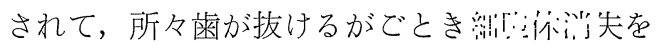
認めた。このととより, コルチ器上方回転では $\mathrm{OHA}$ より IHG の方がKM， SM 障害され 易いと判断される。

下方回転では $\mathrm{OHC}$ が IHG より強く障害 され，OHCがすべて消失した段階でも IHC は光顕的には全く健常な整然とした細胞列を残 していた，上方回転で OHG の消失のなかっ た内耳では, 上方回転 IHG がすでに変化を受 けていても下方回転では $\mathrm{OHC}, \mathrm{IHC}$ とも変 化を認めなかった。下方回転では，乙のてとよ り，上方回転とは逆に $\mathrm{OHC}$ がより障害され 易いととが判った。 
コルチ器では上方回転 IHCが最も障害され やすく，次いで下・上方回転 $\mathrm{OHC}$ が障害さ れやすいものと考えられ，下方回転 IHCは

KM，SMに最も抵抗性を示した。

前庭器官における KM，SMによる変化を以 下に述べる。前庭器官における変化も KMと S Mで差は認められなかった。

球形のう, 卵形のうの平衡玟ではいずれの部 位寻 Striola 部の I 型・II型細胞の両者を強く 障害し，それに反して Striola 部以外の周辺部 ではほぼ完全な形で I 型・II型細胞とも残存し ていた（図 1). Striola 部の病変が軽い場合， I 型細胞の障害が先行し， II 型細胞は残存して

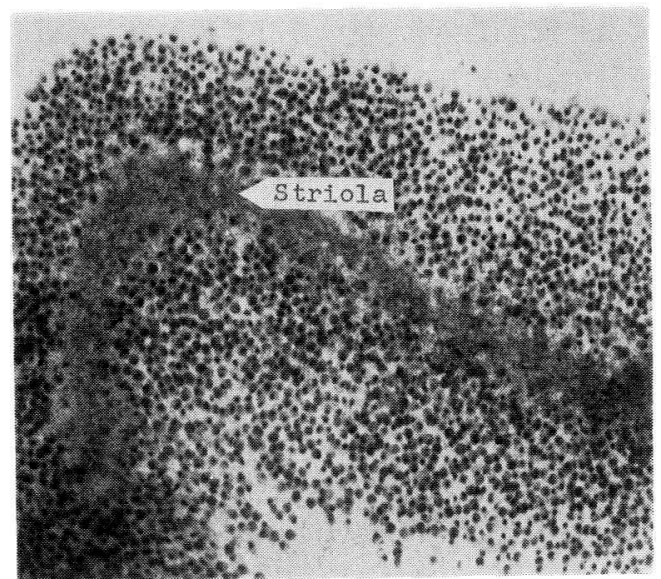

図 1.200 mg $/ \mathrm{ml}$ 濃度 $\mathrm{SM}$ 注入内耳の球形のう 斑. Striola部の感覚練胞は全んど消失して いる. (SDH 染色)

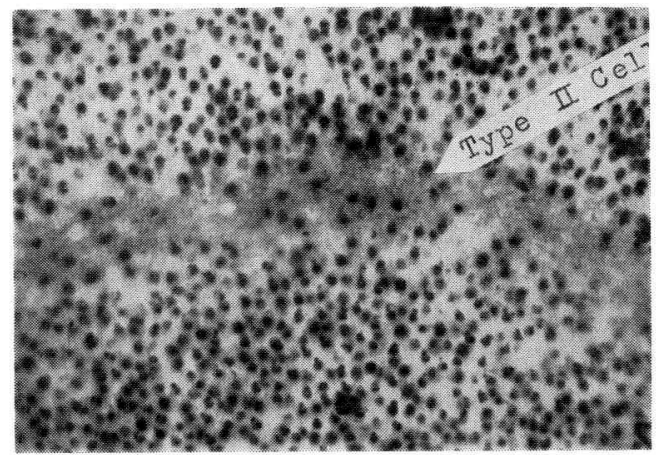

図 $2.200 \mathrm{mg} / \mathrm{ml}$ 濃度の $\mathrm{SM}$ 注入内耳の球形の う斑. Striola 部に II 型細胞のみが散在性 に残存している。(SDH 染色)
いる像も認められた（図 2)。このととより， 平衡斑では Striola 部に病変が限局し, Striola 部では I 型よりも II 型細胞の方がKM， SM 抵抗性を示すことが判った。

半規管膨大部稯では，水平半規管，前半規管 での変化が強く, 後半規管でも変化は強く認め られたが同一内耳で比較するとその程度はやや 軽いように思われた，膨大部稜での変化は中央 部 (頂部) で最も強く，周辺部（裾部）へいくに 従って次第に変性・消失した細胞の数は減ずる が，乙の場合も平衡斑で認められたと同様に I 型紏胞の消失が II 型細胞の消失に先行した。た だ膨大部稜では紐胞の変性，消失は中央部より 連続的に周辺部へ拡大しており，平衡斑にみら れるような， Striola 部を離れると細胞の抵抗 性が急に増大して非常に強固になるといった傾 向は認められず，病変部と健常部の境が明瞭で はない(図 3 )。中央部の I 型細胞が消失し少数 の II 型細胞を残している段階で，I型細胞の変 性はかなりの程度まで周辺へ拡大している像が 認められた。

鼓室内注入による毛紐胞障害の様式を $\mathrm{KM}$ と SMで正常像と比較して図 4 亿示した.

\section{投与薬剤の濃度差による毛細胞変性像の変化} について

注人される $\mathrm{KM} ， \mathrm{SM}$ の濃度を低くしていく と，当然外リンパ腔を経て毛細胞に達する薬剤

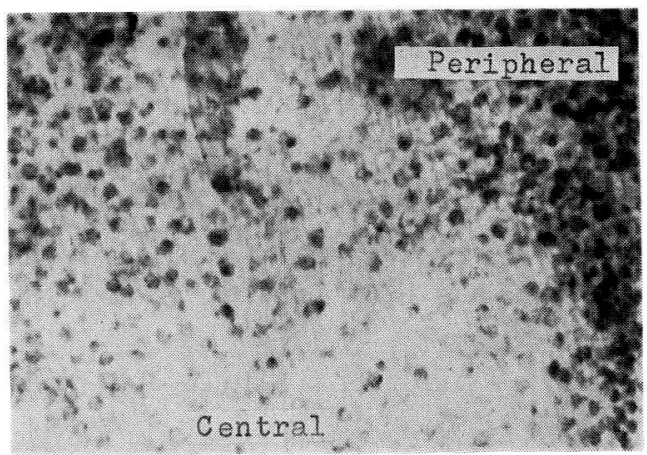

図 3. $200 \mathrm{mg} / \mathrm{ml}$ 濃度の $\mathrm{KM}$ 投与内耳水平半 規管膨大部稯感覚上皮，中央部での毛細胞 変性消失が著しく，周辺部へいくにしたが って正常細胞か増えてくる。(SDH 染色) 




図 4. $200 \mathrm{mg} / \mathrm{ml}$ 濃度の $\mathrm{KM}$ および $\mathrm{SM}$ 注入内耳における障害度の比較 ( $\mathrm{SDH}$ 染色) $\mathrm{KM}$ と SM で同程度の同一樣式の毛細胞障害が認められる。

の量も少なくなるため, それに従って毛細胞病 変は軽くなっていく訳であるが，毛細胞障害を ひきおこすのに必要な最低濃度での変性像は内 耳の中で最も抵抗性の弱い部位に限局して現わ れるものと考えられる。先に述べたように，乙 の群では KM， SMともそれぞれ， $50 \mathrm{mg} / \mathrm{m} 1$, $100 \mathrm{mg} / \mathrm{ml}, 200 \mathrm{mg} / \mathrm{ml}$ の 3 種の濃度をもった 水溶液を注入して観察した。断頭はすべて投与 後 1 週間で標本を作成した。

$50 \mathrm{mg} / \mathrm{ml}$ 濃度の $\mathrm{KM}$, SMを注入した内耳 では,コルチ器でも前庭器でも全く毛細胞変性 を認めなかった。

$100 \mathrm{mg} / \mathrm{ml}$ 濃度のKM，S M 在注入した内耳 では, コルチ器上方回転で毛細胞変性が涩めら れ，IHC，OHCの一部に細胞体消失在浔めた。 コルチ器下方回転および前庭器官では全く変化
在認めなかった（図 5 ）。

以上のととから，コルチ器上方回転の IHC および OHC が最も抵抗性の弱い部分である ととが判った。

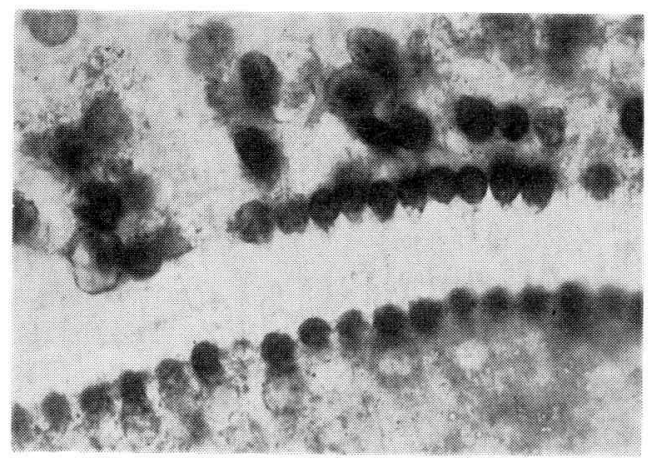

図 5. $100 \mathrm{mg} / \mathrm{ml}$ 濃度 $\mathrm{KM}$ 注入一週間後のコル 于器第 4 回転, (SDH 染色) 
$200 \mathrm{mg} / \mathrm{ml}$ 濃度の KM，SMによる毛紲胞変 性の様式については前項で述べた.

\section{投与後の経時的変化について}

$200 \mathrm{mg} / \mathrm{ml}$ 濃度の $\mathrm{KM} ， \mathrm{SM}$ 鼓室内に注入 された動物は, 注入後約 $3 \sim 4$ 時間で非注入側 一向う水平性自発眼振および注人側への転倒傾 向を示した。このととから, 動物は注入後 3 4 時間の時点ですでに注入側の迷路機能失調を 来しているものと想像されるが，乙の時断頭し て観察した内耳は光顕形態学的には何らの変化
も示していなかった，水越 ${ }^{14)}$ 単離有毛紐胞の 膜構造の変化を経時的に追う奏験から, 内耳毛 細胞が KM， S Mの影響を受けて膜の興奮機能 を失してから光顕形態学的変化という終局的な 変性像を示すまでに一定時間を要すると述べて いる様に，今回の実験条件においても，毛紐胞 変性を光顕的にとらえ得るまでにはかなりの時 間を要した。

KM，SMによる毛細胞障害機構の詳細に関 しては不明の点が多いが, これらアミノ配糖体
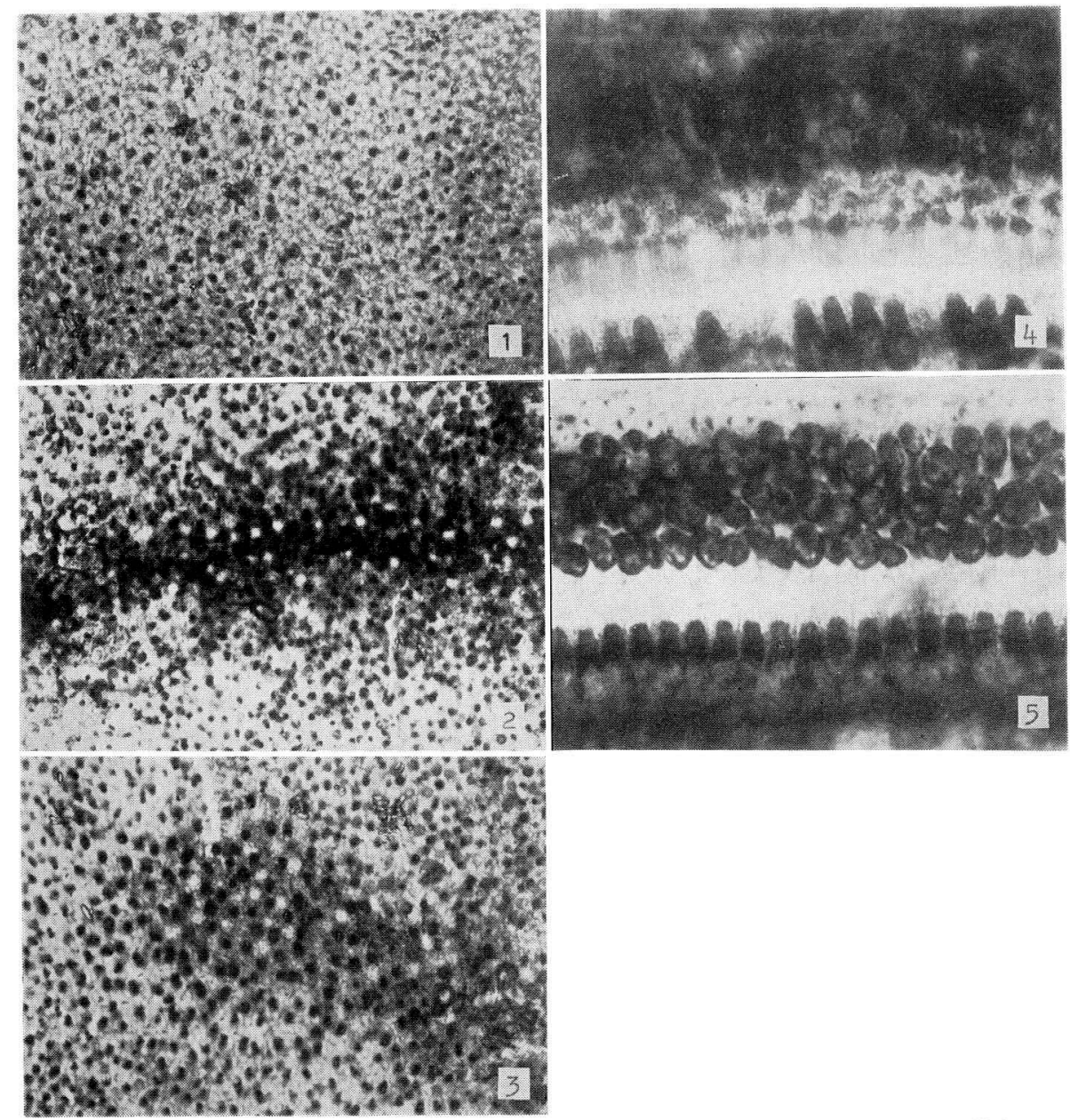

図 6. $200 \mathrm{mg} / \mathrm{ml}$ 濃度 $\mathrm{SM}$ 注入，48時間後の内耳各部位での毛細胞病変，コルチ器上

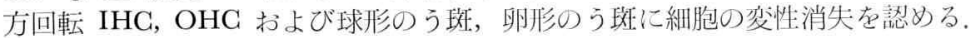
(SDH 染色)

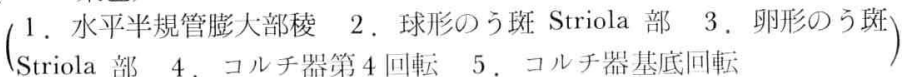


系抗生物質は強い陽イオンとしての性格を有し ており ${ }^{14)}$ ，てのことにより，てれら抗生物質が 膜表面の陰性荷電 ${ }^{19}$ そ吸着され易い性格を示す と同時に，一部膜構成々分と置換され ${ }^{14)}$ ，膜構 造を変化させてしまうことが第一次的な障害作 用であろうと想像されている。しかし，ての段 階の変化は光顕形態学的な変化としてはとらえ 難く，乙れら抗生物質が細胞内にとりてまれ て，細胞内代謝機構を障害するという第二次的 な段階での変化が進行して形態変化を惹起し， はじめて光顕的形態変化としてとらえられる. 以上の考光方加らすると，終局的にとらえられ る形態变化は，最初の膜変化および細胞内代謝 障害といった機能的変化を受ける程度に比例し て現われるものと思われ，早く強く機能的変化 を受けた部位は，早く強く一定時間後に形態変 化を示すものと考えられる。

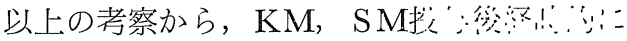
形態变化を観察し，乙れら抗生物質に最も早く 強く障害される部分を形態学的にとらえようと

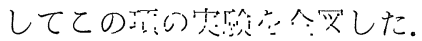

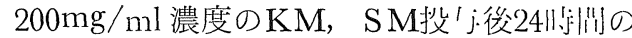
内耳ではほとんど形態変化を認めなかった。

\section{考}

\section{$\mathrm{KM}$ と SM での障害部位の異同について}

1951年，Berg ${ }^{2)}$ が猫の内耳に対するストレプ トマイシンの影響について報告して以来，アミ 八配当体系抗生物質の内耳障害性に関する実験 们推繁例の報告は多いが，現在までの多くの報 告は，コルチ兴洲:!の観察には動物にKMを投 与している場合が多く，まだ行察 には SMを投与している場合が多い。逆にKM

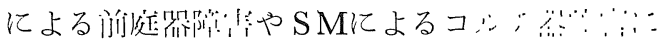
言及して比較検討をおてなっている研究は少な い.

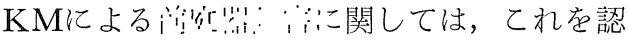
めるとする報告よりも，認めずとする報告の方 が多い，例えば，W Ward ${ }^{28)}$ は球形のう，卵形の

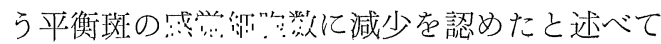

投与後48時間を経過すると，コルチ器上方回 転で OHC は第I 列から，また IHG は穊状 に障害されて，とてろどてろ’”’”、“失を来し ている像を認め，下方回転ではいまだ細胞体の 外形は保持しているが，しばしば OHG で細 胞体の著しい 膨化を来している像が 観察され た。前庭器ではほぼ正常の形態を保っている が，詳縕に钼察すると多くの耳石器平衡斑で点 状に I 型細胞の消失を認め，乙の傾向は卵形の うより球形のうに著しかった（図 6 ).

以上の結果より，コルチ器上方回転 $\mathrm{OHC}$ および IHC，ならびに球形のうの I 型細胞が 最も早く障害されることが判った。

\section{対照例の観察}

生理的食塩水を投与した内耳技よび $5 \% ， 10$ $\% ， 20 \% ， 40 \%$ 各庶糖液を投与した内耳で は，強い化膿性中耳炎を併発していたが，内耳 に炎症が波及したと思われるものを除いては， すべての内耳で毛細胞は正常の形態を示し，一 時的な外リンパ腔中のイオン組成変化および渗 浱厂:多化 ${ }^{22)}$ では毛細胞に光顕形態学的な变化を 示さないことが判った。

\section{按}

いるが, Hawkins ${ }^{10)}$, Portmann ${ }^{18)}$, Farkashidy 7)は何ら変化を認めていない，Lindemann ${ }^{13)}$, 綿貫 ${ }^{30)}$ ，Watanuki ${ }^{31)}$ はKM障害はコルチ器に

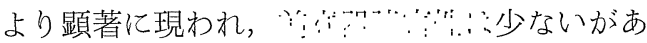
る程度認められるとしている。

一方，SMによるコルチ器障害に関しては， これを認めるとする報告よりも，やはり認めな いとする報告のほうが多い，例えば， Berg $^{2)} は$ 猫を用いて実験を行ない，多くの実験動物のう ち一匹のみで蝸牛第一，第二回転に若干の細胞 消失を認施と述べ，また，Duvall ${ }^{14)}$ は極く

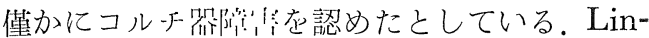

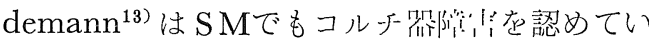
るが，Lindemann はこの実験に鼓室内注入法 を用いており，著者の実験結果と一致するとと 


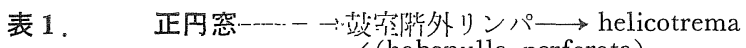

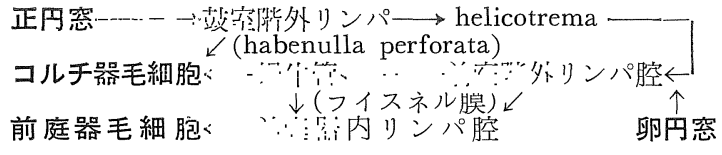

ろとして，全身投与時の変化とは異ってコルチ 器障害を認めたものと考えられる。

以上の文献に見られるように，多くの報告で は KM， SMを筋肉内あるいは腹腔内に投与し て血行を介して内耳に達せしめると，KMはコ ルチ器を主に障害し，SMは前庭器を主に障害 しているてとが判る。しかし，今回著者がKM， SMをモルモット鼓室内に投与しておてなった 実験では,コルチ器と前庭器で両薬剤に対する 易傷性の差は認められなかった。

一般に，薬剤を鼓室内に投与した場合，内耳 毛細胞に達する経路は表 1 のように考えられて いる。

コルチ器毛細胞に薬剤の達する経路が, 経ラ イスネル膜によるのか, habenulla perforata を介してコルチリンパ呮から達するかは議論の あるととろであるが, Kohonen ${ }^{11)}$ は helicotrema から前庭階外リンパ腔 $\rightarrow$ ラスネル膜 $\rightarrow$ コルチ器毛細胞の䋂䇋を想道しており, また著

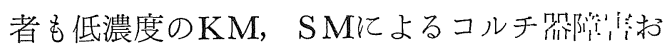
よび投与後短時間での障害がコルチ器上方回転 に限局していたてとから，早期に KM, SM さらされるのはこの部位であるために，KM，

SMによる初期変化をコルチ器上方回転に限局 して認めたという考光方に立って，正円空から 侵入した KM，SMは鼓室階を上昇して helicotrema で回州し，ライスネル膜を介して毛 細胞に達する経路が主流であると想定した。し かし，いずれの経路をたどるにしても，鼓室内 飞 $200 \mathrm{mg} / \mathrm{ml}$ 濃度の $\mathrm{KM}, \mathrm{SM}$ 投与すると いう条件では，全身投与時に観察される外リン パ腔中濃度のレベルと比較しても，それと比較 にならないくらい大量の $\mathrm{KM}, \mathrm{S} M$ が正円空, 卵円空を介して，しかも短時閒に外リンパ腔に 侵入するととになるので，投与されたKMは

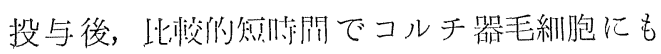

前庭器毛細胞にも均等に達するものと考えら れ, ての時点ではコルチ器毛細胞も前庭器毛細 胞も同一条件下でKM，SMKさらされている ので，その維赑微然される毛細胞の障害様式は 各部位の毛細胞が充分に均等にKM, SM $\mathrm{K}$ 亿接 した場合の毛細胞障害様式と考えられる。すな わち, コルチ器毛細胞も, 前庭器毛細胞も $\mathrm{KM}$, SMに接すればいずれもたやすく障害される訳 で，乙の際いずれの毛細胞もKMあるいは SM に対して特異的な易傷性の差を示すてとはな い，KM，SMを全身的に投与した場合には， 投与部位より血行を介して内耳毛細胞に達する 訳であるが, この場合に, コルチ器と前庭器で KMあるいはSMのそれぞれに対する易傷性に 差を生ずるとすれば，今回の実験結果より，そ れは各部位の巨紃胞に到達するあるいは集積す る KMと SMの量が部位的にそれぞれ異なった 分布を示すための障害様式の違いと考えるのが 妥当である。つまり，KMはコルチ器毛細胞部 位により多く集まり, 逆に SMでは前庭器毛細 胞部位により多く集まると考える訳であるが， 一方でKMと SMでは非常に似かよった化学構 造を有しており，その抗菌作用の機序も同様で あるととから，乙れらの薬剤が到達経路のいず れの部位で, いかにして特別の場所へふり分け られるのかは現在のとてろ判然としない。しか し，渡辺 ${ }^{29)}$ は外リンパ腔と内リンパ腔の間に blood-brain barrier 様の barrier の存在を想 定しており，また，著者ら ${ }^{26)}$ が一般に内耳障害 性を有さないとされているテトラサイクリンの 誘導体であるミノサイクリンで，わずかに側鎖 が変化しただけで，内耳障害性を示した実験例 を報告しているように，ある柯の扰师物馆が内 耳障害性を発揮するか否かは，いずれかの部位 の barrier を越え得るか否かにかかっている可 能性が溞く，しかも抗生物質ではその側鎖の僅 
かの違いが barrier 通過性を大きく支配してい るものと考えられる.KMとSMで内耳毛細胞 部位への透過性あるいは分布動態が僅かの側鎖 の変化で異ってしまう可能性は充分考えられ る.

\section{KM, SM による内耳障害の各部位での特異} 性について

$200 \mathrm{mg} / \mathrm{ml}$ 濃度の KM，S S 投与後 1 週間目 亿観察される内耳毛細胞障害の様式は各部位で 特異的な現われ方をしており，全身投与時の

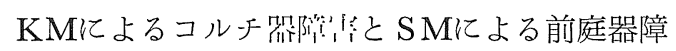
害を合せたような障害像を示した(図7).

コルチ器では, 下方回転で IHC がKM, S Mr強い抵抗性を示しているのに, OHCは強
く障害され，逆に上方回転では IHG の障害の 方が OHG の障害より強く現われている。

コルチ器毛細胞障害様式に関する研究は多 く, 多くは動物に $\mathrm{KM}$ を投与して観察してい る.

OHG の障害のパターンに関しては, Hawkins $^{10)}$ はKMを投与した猫で OHG 障害は第 1 , 第 2 回転に限局し，モルモットでは全回転 に及ぶとした。 Portmann ${ }^{17)}$, Ward \& Ferna$\mathrm{ndez}^{28)}$ らはモルモットにおいては KMの場合 OHC 障害は下方回転でより強いとしている. Engström ${ }^{6)}$ は surface preparation 法を用い て観察し，KMによる $\mathrm{OHG}$ 障害は第 1, 第 3 回転で強く, 第 2 , 第 4 回転での変性は軽微

COCHLEA

\section{0}

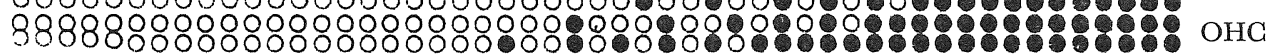
APEX

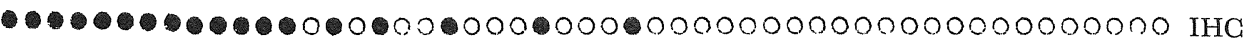

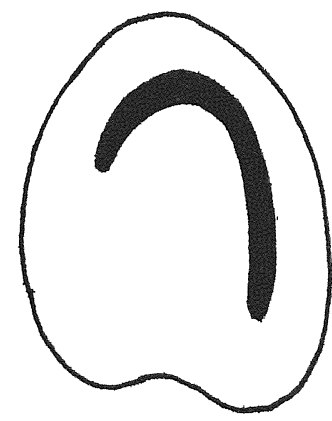

UTRICLE

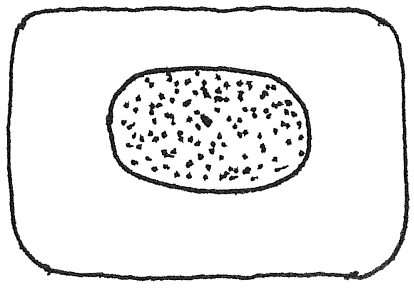

POST. AMPULA

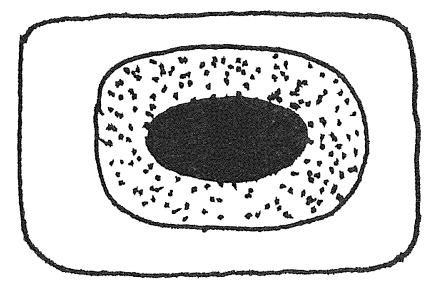

ANT. AMPULA

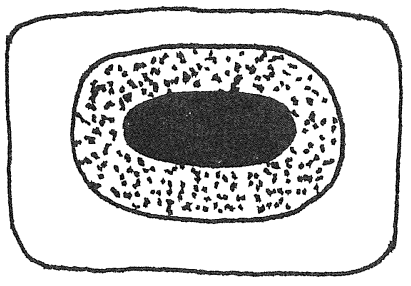

LAT. AMPULA

図 7. $200 \mathrm{mg} / \mathrm{ml}$ 濃度の $\mathrm{KM}$ または $\mathrm{SM}$ 鼓室内注入による感覚細胞の障害部位（黒 い部分が細胞消失部位を示す) コルチ器では上方回転内毛細胞 (IHG), 下方回 転外毛細胞 $\mathrm{OHC}$ が消失している. 耳石器平衡斑では Striola 部のみが選択的 に障害されるが，膨大部稜感覚上皮では，周辺部より中央部へ進むにしたがっ て, 次第に消失細胞数が増えてくる. 外, 前半規管膨大部の障害が, 後半規管 膨大部での障害より強くあらわれ, 耳石器平衡斑, 膨大部稜ともに I 型細胞の 障害が II 型細胞の障害に先行した。 
であるとし，一般に OHG 障害は基礎回転の 第 1 列より始まるとしている。乙の $\mathrm{OHC}$ 障 害の始まりが基礎回転第 I 列であるとする考え 方は, $\mathrm{Beck}^{1)}$ ，半藤 ${ }^{9)}$ る認めるとてろである。 Lindemann $^{13)}$ は腹腔内に投与したKMも，鼓 室内に注入した SMも共にコルチ器毛細胞を障 害し，一般に OHA では下方回転で強い障害 性を認めている。一方で，モルモットでKM，

$\mathrm{SM}$ による $\mathrm{OHC}$ 障害が頂回転で最も著しい との報告もみられた ${ }^{27)}$.

IHC の障害の様式に関しては, Lindemann ${ }^{13)}$ の上方回転でより障害され易いとの報告の他 に, Hawkins ${ }^{10)}$ は逆にモルモットでは第 1 , 第 2 回転に限局し，人でも主に基礎回転に限局 されるが，猫では全回転に亘って障害を認めた として, 全体の傾向としては IHG も $\mathrm{OHG}$ と同様KMに対して下方回転でより障害を受け 易いとしている. Ward \& Fernandez ${ }^{29)}$ も下 方回転 IHC の易傷性を認めている. Engström 6) はモルモットの場合, IHG 障害は OHCの それより遅れて，頂回転より始まり次第に下方 へ拡大すると述べている。

以上の報告に見られるように，コルチ器毛細 胞は回転ごとにアミノ配糖体系抗生物質に対し て感受性が異なり, 易傷性を示す部位に関して は各報告で異なるが，現在のとてろ一般に下方 回転 $\mathrm{OHC}$ および上方回転 IHG が実験条件 のいかんにかかわらず障害を受けやすいと考光 られている。水越ら ${ }^{15)}$ は正常モルモットのコル チ器では, $\mathrm{SDH}$ 活性が下方回転 $\mathrm{OHG}$ およ び上方回転 IHC で他の部位に比して強い活性 を示すととから，酸素消費率の高い部位が細胞 内代謝阻害因子に対してょり labile であると の考えに立脚して，ての部位で $\mathrm{KM} ， \mathrm{SM} と ゙$ の代謝阻害物質による障害が顕著となると述 べ，一方 Mizukoshi ${ }^{20)}$ は microrespirometry を応用してコルチ器で各回転別の酸素消費量を 測定し，下方回転での酸素消費率がより高いこ とから下方回転での毛細胞易傷性に対する根拠 を水越ら ${ }^{5)}$ と同様の立場から説明している。
今回の実験条件では，正円空より侵入した KM，SMは高濃度であれば一定時間後に蝸牛 各回転毛細胞にほぼ均等に達するものと考光ら れ，乙の条件下で上方回転 $\mathrm{IHC}$ ，下方回転 $\mathrm{OHC}$ に限局して障害を認めたてとは，コルチ器の各 部位で細胞レベルでの易傷性の差の存在を示し ている。水越 ${ }^{14)}$ は音受容の機構に関して, $\mathrm{OHG}$ は音振動の受容を受けもち，IHG は入ってき た音振動の Intensity を調整する機能を分担し ているととをKM障害内耳での GM, EP 変動 より解析し明らかにしているが，音振動の変換 器としての OHC のエネルギー消費率はより 多くの周波数で振動する下方回転でより高度で あるととが考えられる。䊶織化兴似に下方回転 $\mathrm{OHC}$ と上方回転 IHC でより高い酵素活性を 示しているととと一致して，ての部位での代謝 レベルが他の部位に比して高いてとが想像され るが，乙のためにKM， SMなどの代㴬阴、乼物 質がこれらの部位に特異的に強い障害性を示す ことが考えられる。

一方, 前庭器での毛細胞障害は KM, SMの 両者で図 7 の如き障害像を示しており, 水平 .

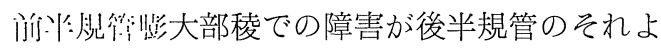
りやや強く, 平衡斑では球形のう斑の障害が卵 形のう斑のそれより強かった。膨大部棱におけ る変性の程度と平衡斑における変性の程度は, 後に述べるように変性のパターンが異なって おり，正確な比較は困難であったが，初期変化 として毛細胞変性を最も早く現わしたのは球形 のう斑であった。

各前庭器官での易傷性の順位に関しては，鈴 木 ${ }^{25)}$ はモルモットにSMを投与して，水平半規

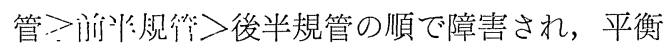
斑では卵形のう>球形のうの順で障害され易い と述べ, Lindemann ${ }^{13)}$, 綿貫 ${ }^{30)}$ はモルモットに SMを鼓室内法で投与して, 膨大部稜>梱形の う斑〉球形のう斑の順で障害され易いと述べて

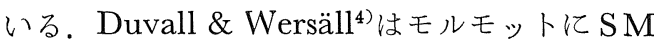
を投与して，膨大部稜と平衡斑で易傷性に差は ないとし，Berg ${ }^{2)} は$ 猫における S M障害では卵 
形のう斑での障害が球形のう斑のそれより強い と述べている。

以上より，一般に各前庭器官間での易傷性の 順位は, 水平・前半規管膨大部稜での障害が後 半規管膨大部稜での障害より強いとされ，今回

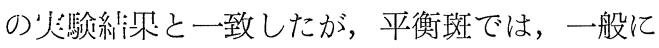
卵形のう斑での障害が球形のう斑での障害より 強いとされているが, 今回の実験では逆の結果 が得られた。乙れは鼓室内注入時の薬剤の侵透 が正円㥶により近い部位より始まるてとから， 蝸牛管あるいは蝸牛前庭階よりの侵入門戸に位 置する球形のう斑でより強い障害が認められた のではないかと考える。

膨大部稜での毛細胞障害は感覚細胞層の中央 より始まり, 病変が進展するに従って周辺部へ 変性が拡大しているのを認めた。 I 型細胞の変 性が型細胞の変性に先行した。平衡斑での毛 細胞変性はほほ Striola 部 $\left(\right.$ Werner ${ }^{32)}$ ) そ限 局し，その他の部位では，Striola 部に健常な 毛細胞が全く認められなくなった段階でも，極 く僅かの I 型細胞の脱落を見るにとどまった.

平衡斑 Striola 部が機能的に重要な意味をも っているととは，鈴木 ${ }^{24)}$ が SMにより平衡斑 Striola 部に軽度の変性の認められたモルモッ トですでにかなりの程度に立直り反射の失調を 来しているととからもとの部の㙨能似な重要性 は類推される. 正常モルモットで平衡斑 Striola 部は周辺部に比して，はっきりと境されて SDH 強活性を示し，てのととからもとの部位が身体 平衡維持に重要な役割を果しているととが類推 され，高度の代謝活性を有しているために，K

$\mathrm{M}, \mathrm{S} \mathrm{M}$ な゙゙の代謝阻害剤にての部位が特異的 に障害され易いことも理解できる。平衡斑での 障害は Striola 部 I 型細胞に始まり, 次いで Striola 部 I 型細胞が障害される。.Striola部を 離れると I 型, II 型両者とも $\mathrm{KM}, \mathrm{SM}$ 亿抵抗 性を示し，ごく僅かの I 型細胞の脱落が認めら れるにとどまるととからも， Striola 部の機能 面での特異的な役制が想像される。

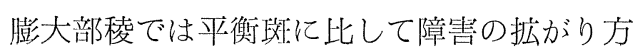

はばくぜんとしており，Lindemann ${ }^{13)}$ が述べ ているような中央部と周辺部の境は認められず 連続的に変性が拡大している。乙の場合, I 型 細胞の障害が主流をなし，中央部に一部凹型細 胞の残存している状態でもI 型細胞の消失はか なり周辺まで拡大していた。正常モルモット膨 大部棱では中央部で I 型細胞が多く存在し, 周 辺部へいくに従って II型細胞の比率が多くな り, 叉, 中央部の毛細胞は I 型, II型とも周辺 部の毛細胞より大型で分布もまだらであるが, その境は明膫ではなく分布形態の移行は連続的 である。鈴木 ${ }^{24)}$ は膨大部稜での感覚受容機構に 関し, 膜迷路中の内リンパ夜の流動状態の考察 から，中央部になる程鋭敏に刺激を感受する必 要のあるととを述べているが，こてでの感覚受 容の様式は平衡斑において Striola 部が有して いたような特異的な役割を果す部分が存在する 必要はなく, 頂上部から裙部へいくに従って連 続的に毛細胞の興奮閾值が上景していく構造を 有しているととが要求される，以上のてとから も, 膨大部稜での細胞内代謝活性は中央部から 周辺部へ連続的に変化していくものと思われ， SM，KMなどの代謝阻害因子により連続的に 中央部より障害されてくる理由が理解できる。

ところで，一般にアミノ配糖体系抗生物質が 前庭感覚上皮を障害する場合，I 型細胞が II 型 細胞より障害され易いとされている(4)13)12)23)24) 25)26)30331)。前庭感覚上皮における I 型, II 型細 胞の易傷性の差について, 綿貫 ${ }^{30)}$ は I 型と II 型 の周辺支持細胞との相関々係に着目して述べて いるが，Winter ${ }^{33)}$ は X線照射による前庭器障 害では，障害が周辺部で強く，しかも升型細胞 の障害が I 型細胞の障害より強いととを示唆し ており， I 型およびII型細胞の障害性の差異に 関しては未だ不明の点が多く残されている。た だ膨大部稜においてはより鋭敏な刺激感受機構 を有すると思われる頂上部で I 型細胞がより多 く分布しており，また，SDH 活性はI 型の方 が型より高いととから，I 型細胞が II 型細胞 よりも高い代謝活性を示し，したがって刺激に 
対する反応閾值も低いととは確かであるが，そ の機能分化の意味は不明である， KM, SMな

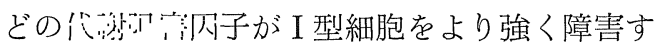
るのは，I 型細胞での代謝活性の高いととと関 連をもっていると考える。

以上の考察から，内耳毛細胞においては，コ ルチ器でも前庭器でも機施们に门裂な役割を果 していると考えられる部位で毛細胞は高い代謝 活性を有しており，したがって SM，KMなど の代謝阻害因子によってそれらの代謝活性の高
い部位より障害されていくものと考えられ，こ の障害様式は，おそらくはKM， SMrかぎら ず，全ての代謝阻害物質に共通のものと考えら れる。

$\mathrm{KM}, \mathrm{S} M$ Kよる毛細胞障害は毛細胞の特異 的なアミノ配糖体に対する感受性によるのでは なく，KM，SMという代謝阻害因子がたまた ま, 特異的に高い内耳移行性あるいは貯留性を 有するために毛細胞障害を発来するものと思わ れた。

\section{ま と め}

1. $\mathrm{KM}$ および $\mathrm{SM} モ ル モ ッ ト$ 鼓室内に注入して内耳毛細胞変性様式を光顕形態学的に検索し たが， KM， SMの両者において，その障害様式は同一であり，毛細胞はコルチ器においても前庭 器においても KM，SMに接しさえすれば，同程度に障害されるととが判った。

2.コルチ器における毛細胞変性は，KM，SMの両者で, 上方回転内毛細胞, 下方回転外毛細 胞に強く現われ，乙の障害部位は機能的に重要な役割を果す部位および組織化学的に高い代謝活性 を示す部位に一致した。

3. 前庭器における毛細胞変性は, $\mathrm{KM}, \mathrm{SM}$ の両者で, 平衡斑 Striola 部, 膨大部稜中央部に 強く現われ，乙の障害部位は機能的に重要な役割を果す部位および組織化学的に高い代謝活性を示 す部位に一致した。

4. 前庭毛細胞のうちで I 型細胞の変性がII型細胞の変性より高度に認められ，ての障害度の違 いは I 型細胞が II 型細胞より高度な機能を有しており，高い代謝活性を有しているためと考えられ たが，その機能分化の意味については不明であった。

5. 鼓室内注入による毛細胞変性は，対照実験より，非特異的変化ではなく，KM， SM そよる 特異的な代㴬阴1行によるものであることが判った。

本論文の要旨は第 20 回内耳生化学会, 第 17 回日本オージオロジー学会, 第 31 回日本平衡神経科学会に扔いて 発表した。

稿を終えるにあたり，御指導御校閲をいただきました水越治教授に深謝致します。

また，実験の当初より御指導御教示をいただきました大阪鉄道病院耳鼻咽喉科鈴木政昭博士に謝意を表しま す.

\section{文献}

1) Beck. C. and Krahl, P. : Experimentelle und feingebebliche Untersuchungen über die Ototoxizität von Kanamycin. Arch Ohr, Nas.-u. Kehlk. Heilk. 179 : 594, 1961.

2) Berg, K. : The Toxic Effect of Streptomycin on the Vestibular and Cochlear Apparatus. Acta otolaryng. suppl. $97: 1,1951$

3) Brown, H.A. \& Hinshow, H,G, : Toxic Reaction of Streptomycin on the Eighth Nerve Apparatus. Proc. Statt. Meet., Mayo Clin. 21 : 347, 1946.

4) Duvall, A.J. \& Wersäll, J. : Site of Action of Streptomycin upon Inner Ear Sensory Cells. Acta otolaryng. $57: 581,1964$.

5) Engström, H., Ades, H. \& Hawkins, J. : Structure and Functions of the Sensory Hairs of 
the Inner Ear. J. Acoust. Soc. Am. $34: 1356$, 1962.

6) Engström, H. \& Hawkins, J. : Effect of Kanamycin on Cochlear Architecture. Acta otolary" ng. suppl. $188: 102,1964$.

7) Farkashidy, J., Black, R.G. \& Briant, T.D.R. : The Effect of Kanamycin on the Internal Ear : An Electrophysiological and Electron Microscopic Study. Laryngoscope 73 : 713, 1963.

8) Floberg, L.E., Hambarger, G.A. \& Hydén, H.: Inhibition of Nucleic Acid Production in Vestibular Nerve Gells by Streptomycin. Acta otolaryng. suppl. $97: 1,1951$.

9) 半藤怜子 : コルチ氏器のカナマイシンに対する受 傷性に関する研究 耳鼻臨 : 57 : 3, 428, 1964 。

10) Hawkins, J. : The Ototoxicity of Kanamycin. Ann. Otol. 68 : 698, 1959.

11) Kohonen, A. \& Tarkkanen, C. : Cochlear Damage from Ototoxic Antibiotics by Intratympanic Application. Acta otolaryng. 68 : 90, 1969.

12) Lindeman, H.H. : Cellular Pattern and Nerve Supply of the Vestibular Sensory Epithelia. Acta otolaryng. suppl. 224 : 86, 1967.

13) Lindeman, H.H. : Regional Difference in Sensitivity of the Vestibular Sensory Epithelia to Ototoxic Antibiotics. Acta otalaryng. 67 : 177, 1969.

14）水越 治：内耳毛細胞の病態 日耳鼻，75:11; 1300, 1972 .

15）水越 治, 斉藤 等, 鈴木政昭, 佐藤良暢：螖牛 !化息现象し部位的特異性 耳鼻 $16: 2 ; 51$, 1970.

16) Mushett, G.W. \& Martland, H.S. : Pathologic Changes Resulting from the Administration of Streptomycin. Arch, Path. 42 : 619, 1946.

17) Portmann, M. : Etude experimentale de l-action antitoxique de cellules de l'organe de Corti. Acta otolaryng. $57: 266,1964$.

18) Rüedi et al : Über die Lokalization der Streptomycinschädigung in den Statoacusticuskernen des Meerschweinchens. In Fanconi und Löffier : Streptomycin und Tuberkulose. B. Schwabe \& Co., Basel. 261, 1948.
19) Saito, H. \& Daly, J.F. : Quantitative Analysis of Acid Mucopolyacchalides in the Normal Guinea Pig Gochlea. Acta otolaryng. 69 : 333, 1970.

20) Mizukoshi, O. \& Daly, J.F. : Oxygen Consumption in Normal and Kanamycin Damaged Cochlea. Acta otolaryng. 64: 45, 1967.

21) Stevenson, L.D., Alvord, E.C. and Correll, J.W. : Degeneration and Necrosis of Neurones in Eighth Cranial Nuclei Caused by Streptomycin. Proc. Soc. Exp. Biol. \& Med., 65 : 86, 1947.

22) Spöndlin, H. : Zur Ototoxizität des Streptomyzins. Pract. otorhinolaryng. 28 : 305, 1966.

23）鈴木政炤, 中村文雄 : 前庭膜迷路の cytoarchitecture. Vestibular Research 18 : 69, 1966.

24）鈴木政昭：前庭膜迷路の形態学的および糺織化

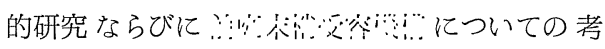
察. 日耳鼻 $75: 11 ; 1300,1970$ 。

25）鈴木政炤 : 感覚細胞の障害度と前庭反応 Equilibrium 31 : 119, 1972.

26）豊田弥八郎, 鈴木政昭 : 乏ノサイクリンのモルモ ット内耳に及ぼす影響 耳鼻臨 $65: 11 ; 1269$, 1972.

27) Voldlich, L. : The Kinetic of Streptomycin, Kanamycin and Neomysin in the Inner Ear. Acta otolaryng. $60: 243,1964$.

28) Ward, D.H. and Fernandez, G. : The Ototoxicity of Kanamycin in Guinea Pig. Ann. Otol $70: 132,1961$.

29）渡辺泰夫 : 内耳液とメニエール病の関連性に関す

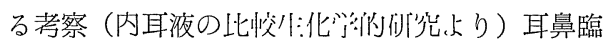
$66: 10 ; 1007,1973$.

30）綿貫幸三 : 前庭感覚器の S MおよびKM中毒の病 理学的研究 日耳鼻 $74: 10 ; 1028,1971$.

31) Watanuki, K. : Toxic Effect of Streptomycin and Kanamycin upon the Sensory Epithelium of the Crista Ampullaris. Acta otolaryng. 72 : 59, 1971.

32) Werner, G.F. : Die Differentierung der Maculae im Labyrinth, insbesonders bei Säugetieren. Z. Anat. Entwickl. Gesch. 99 : 696, 1966.

33) Winter, F. : X-ray Irradiation of the Inner Ear 
of the Guinea Pig. Acta otolaryng. $68: 514$,

/原 稿 到 着：昭和 49 年 2 月 20 日

1969. 